\title{
Demographic Characteristics of Electronic Cigarette Users: A Survey Study
}

\section{Elektronik Sigara Kullanıcılarının Demografik Özellikleri: Bir Anket Çalışması}

\author{
๑ Ayşe Turan ${ }^{1}, \oplus$ Pelin Duru Çetinkaya² ๑ Mehmet Atilla Uysal ${ }^{3}$ \\ ${ }^{1}$ Adana Seyhan State Hospital, Adana, Turkey \\ ${ }^{2}$ University of Health Sciences Turkey, Adana City Training and Research Hospital, Clinic of Chest Diseases, Adana, Turkey \\ ${ }^{3}$ University of Health Sciences Turkey, Yedikule Chest Diseases and Chest Surgery Training and Research Hospital, Clinic of Chest Diseases, Istanbul, Turkey
}

Background: Electronic cigarette (e-cigarette) use is on the rise in Turkey, even though e-cigarettes have been banned since 2013. In this study, the demographic characteristics of e-cigarette users and their reasons for starting and then stopping e-cigarette smoking were investigated.

Materials and Methods: A total of 234 e-cigarette users were selected from social groups using the snowball sampling method in the city of Adana. E-cigarette users were questioned about their demographic characteristics, regular smoking status, reasons for starting e-cigarettes, areas of use, and health symptoms regarding e-cigarette use.

Results: Of the 234 participants, $89.74 \%$ were male, and the mean age was $34.84 \pm 10.15$ (18-63) years; $85.89 \%$ had high school or above education. The participants' three most frequently stated reasons for starting e-cigarettes were a desire to quit smoking completely (74.79\%), the absence of a foul smell (73.93\%), and the wish to avoid the harm of smoking (67.10\%). Of the $234 \mathrm{e}$-cigarette users, 170 reported that they also quit using e-cigarettes. The top three most frequently cited reasons for quitting e-cigarettes were a failure to help to quit traditional cigarettes (26.47\%), the risks of using e-cigarettes $(22.35 \%)$, and concerns about the safety of the product (22.35\%). Responses to the question of how to get e-cigarette devices or liquids were as follows: $45.31 \%$ of users obtained the product from friends, $23.93 \%$ ordered it online, and $30,76 \%$ purchased it from tobacco shops.

Conclusion: Our data show that the most frequent reason to switch from traditional cigarettes to e-cigarettes was quitting smoking. It is worrisome that the users who have made this critical smoking cessation decision, instead of distancing themselves from tobacco, have shifted to yet another tobacco product. This information is an important warning for those in the smoking cessation area to question the availability and comprehensibility of the public's services to help them quit tobacco.

Keywords: Electronic cigarette, smoking cessation, demographic analyses, tobacco use

Amaç: Türkiye'de elektronik sigara (e-sigara) kullanımı 2013 yılından itibaren e-sigara yasaklanmasına rağmen artmaktadır. Bu çalışmada, e-sigara kullanıcılarının demografik özellikleri ve e-sigara içmeye başlama ve sonra bırakma nedenleri araştırılmıştır.

Gereç ve Yöntemler: Adana'da e-sigara kullanmış 234 kişiye sosyal gruplarından kartopu yöntemi ile ulaşılmış ve anket çalışması yapılmıştır. Ankette demografik özellikler, sigara, e-sigara kullanım bilgileri, e-sigaraya başlama/bırakma nedenleri, kullanıldığı alanlar ve e-sigara kullanım esnasında veya sonrasında oluşan sağlık semptomları sorgulanmıştır.

Bulgular: Çalışmaya dahil olan 234 kişinin \%89,74'ü erkek, \%85,89’u lise ve üzeri eğitime sahip, yaş ortalamaları 34,84ะ10,15 (18-63) idi. Katılımcıların e-sigaraya başlama nedenleri sorulduğunda, en sık belirtilen üç neden; sigarayı tamamen bırakma isteği (\%74,79), kötü kokunun olmaması $(\% 73,93)$ ve daha az zararlı olarak algılanması $(\% 67,10)$ olmuştur. Çeşitli nedenlerle e-sigara kullanımını sonlandıran 170 katılımcının belirttiği en sık nedenler; konvansiyonel sigarayı bırakmaya yardımcı olmaması (\%26,47), e-sigaranın riskleri ile ilgili $(\% 22,35)$ ve e-sigaranın güvenliği ile ilgili endişelerdir (\%22,35). E-sigara veya likitlerini sıklıkla (\%45,31) arkadaşlarından/tanıdıklarından, $(\% 23,93)$ internetten, $(\% 30,76)$ çeşitli tütün dükkanından temin ettikleri bilinmektedir.

Sonuç: Bu çalışmada klasik sigaradan e-sigaraya geçişte belirtilen en önemli nedenin sigarayı bırakma isteği olduğu görülmektedir. Bu durum "sigara bırakma" noktasına gelmiş kullanıcıların tütünden tamamen uzaklaşmak yerine yeni bir tütün ürününe kayıyor olmaları tütün kontrolünde kaygı vericidir. Bu bilgi aynı zamanda, halkımıza sağladığımız bilgilendirme ve bırakma hizmetlerini gözden geçirmemiz için önemli bir uyarı niteliğindedir.

Anahtar Kelimeler: Elektronik sigara, sigara bırakma, demografik özellikler, tütün kullanımı

Address for Correspondence: Pelin Duru Çetinkaya, University of Health Sciences Turkey, Adana City Training and Research Hospital, Clinic of Chest Diseases, Adana, Turkey Phone: +90 5327077506 E-mail: pelindurucetinkaya@hotmail.com ORCID ID: orcid.org/0000-0002-4428-8590

Received: 17.03.2021 Accepted: 31.08 .2021 


\section{Introduction}

Electronic cigarettes (e-cigarettes) were introduced to the market in 2004. The product was introduced to the European and American markets in 2006 as a "lower risk" alternative to smoking $(1,2)$. E-cigarettes are battery-powered devices heated below the burning point to generate steam and contain many chemical substances, such as liquid propylene glycol and/or a vegetable glycerin solution. Disposable and refillable types are available (3). Nicotine can be added to the liquid solution in varying concentrations and frequencies, depending on the consumer's requirements.

A wide variety of chemicals, including propylene glycol, glycerol, ethylene glycol, polyethylene glycol (PEG400), diacetyl, diethylene glycol, amino-tadalafil, rimonabant, cannabinoid, nitrosamines, formaldehyde, acetaldehyde ketone, mercury, tetramethylpyrazine, lead, nickel, chromium, nicotine, and artificial flavors, have been identified in e-cigarettes $(4,5,6,7)$. Nitrosamines, known to be carcinogenic, including N-Nitrosonornicotine, 4-(nitroso methyl-amino)-1(3-pyridyl)-butanone, and nitroso-anatabine, have also been found in e-cigarettes (8). Moreover, diethyl glycol, anabasine, myosmine, and beta-nicotryine, proven to be harmful to human health, have been found in e-cigarettes $(6,7,8,9,10)$.

In the United States of America, the prevalence of e-cigarette use among adults was estimated to be $3,2 \%(11)$. In Canada, the prevalence of use was 2,9\% in 2017 (12). In Turkey, e-cigarettes entered the market in 2007-2008, but a 2008 circular of the Ministry of Health banned its sales. Since 2013, the product has been accepted as a tobacco product and included in indoor smoke-free laws $(13,14,15)$. Since e-cigarettes are not legal for sale in Turkey, there has not been a study to report their consumption frequency in the country. However, the use of e-cigarettes is increasing in Turkey as well as in the world. Although electronic cigarettes are not legally available in Turkey, it has been reported that there are 96 active websites that market these products over the internet $(7,16)$. In studies conducted in Turkey, it has been shown that online sales of e-cigarettes and their usage are commonly available (17). Because the increasing prevalence of e-cigarettes raises concerns about possible health risks, it is important to know the user profile to combat populationwide e-cigarette use.

This study investigated the demographic characteristics of e-cigarette users and their reasons for starting and then stopping e-cigarette smoking.

\section{Material and Methods}

Approval for the study was obtained from the Adana Numune Training and Research Hospital Local Ethics
Committee (protocol no: 26.04.2017-57). Verbal consent was obtained from the patients for the questionnaire. E-cigarette users in Adana were recruited from several e-cigarette social groups via the snowball sampling method. Due to the fact that it is a prohibited product, a group not suitable for systematic sampling methods was selected by the snowball sampling method. The prevalence of e-cigarette use in a metropolitan city in the Mediterranean region attracted the attention of researchers, and it was decided to start the study there. Verbal information was given to e-cigarette users about the subject, purpose, and method of the study after 36 patients who came to a state hospital's Smoking Cessation Polyclinic to quit smoking reported their use of e-cigarettes; other e-cigarette users were reached through social networks/media by asking, "who or whom would you recommend contacting" regarding the subject of the research, conveying that personal information would be kept confidential. When the number of 234 was reached, the research was terminated when there were repetitions. The study included 253 individuals aged $\geqslant 18$ years, who had used e-cigarettes for at least one month. However, 12 people did not want to participate for various reasons, and seven people with psychiatric disorders (diagnosis of schizoaffective disorder, bipolar disorder, and major depressive disorder) were not included in the scope. At the time of the study, there was no reliable or valid questionnaire about e-cigarettes. For this reason, the questions of this survey were formed by the researchers based on the literature.

In the first part of the questionnaire, 10 questions about demographic information, smoking and e-cigarette use, and frequency of use were asked. In the second part, the participants were asked to choose the appropriate option from "I disagree," "I partially agree," and "I totally agree" for 13 areas where the reasons for starting e-cigarettes were listed. The time of use of e-cigarettes, the third part, which included information about where it was used, and the 14 areas in which the reasons for discontinuing e-cigarette use were listed, were searched with the options of "disagree," "partially agree," and "completely agree." In the last part of the questionnaire, 18 health symptoms that might occur during or after e-cigarette use were questioned. Eighteen items of categorical data, including health symptoms occurring during or after e-cigarette use, were evaluated. On average, it took about 8-10 minutes to complete the survey.

\section{Statistical Analysis}

Statistical data analysis was performed with the SPSS 16.0 (Statistical Package for the Social Sciences) program. Only descriptive statistics were used in the analysis of the data. In evaluating the data, mean and standard deviation 
were used to describe continuous data, while categorical variables were presented as frequencies and percentages.

\section{Results}

Descriptive analysis showed that $89.74 \%$ of the participants were male, $52.99 \%$ were married, $40.59 \%$ were civil servants, and $85.89 \%$ had a high school or higher education (Table 1 ). The mean age for e-cigarette users was $34.84 \pm 10.15$ years $(18-63)$.

The mean package-year of traditional cigarette users was $14.75 \pm 8.29$. When asked about their tobacco use habits, the average e-cigarette use duration was $3.81 \pm 2.52$ months. E-cigarette users in this group consumed $28.90 \pm 18.9 \mathrm{~mL}$ vials and finished a vial in $13.67 \pm 14.9$ days on average.

The aromas preferred by the participants were fruit (47.86\%, n=112), "other" (pastry, coffee, spices, etc.; 24.80\%, $\mathrm{n}=58)$, tobacco $(14.10 \%, \mathrm{n}=33)$, and mint/menthol $(13.24 \%$, $\mathrm{n}=31)$. The mean nicotine use of e-cigarette users was $4.82 \pm 2.04 \mathrm{mg} / \mathrm{mL}$.

The smoking status of the participants before starting e-cigarettes was questioned: $56.41 \%(n=132)$ reported that

\begin{tabular}{|c|c|}
\hline Sociodemographic characteristics & $n(\%)$ \\
\hline \multicolumn{2}{|l|}{ Gender } \\
\hline Male & $210(89.74)$ \\
\hline Female & $24(10.26)$ \\
\hline \multicolumn{2}{|l|}{ Marital status } \\
\hline The married & $124(52.99)$ \\
\hline Single & $110(47.01)$ \\
\hline \multicolumn{2}{|l|}{ Education status } \\
\hline Illiterate & $4(1.71)$ \\
\hline Primary school & $6(2.56)$ \\
\hline Middle school & $23(9.83)$ \\
\hline High school & $89(38.04)$ \\
\hline University & $102(43.59)$ \\
\hline Postgraduate & $10(4.27)$ \\
\hline \multicolumn{2}{|l|}{ Job } \\
\hline Worker & $46(19.65)$ \\
\hline Officer & $64(27.35)$ \\
\hline Retired & $4(1.71)$ \\
\hline Housewife & $4(1.71)$ \\
\hline Student & $30(12.82)$ \\
\hline Self-employment & $50(21.37)$ \\
\hline Health employee & $31(13.25)$ \\
\hline Other & $5(2.14)$ \\
\hline
\end{tabular}

they smoked regularly, 38.46\% $(n=90)$ were ex-smokers, and $5.12 \%(n=12)$ had never smoked. The change in smoking status after starting e-cigarettes was questioned: $15.38 \%$ $(n=36)$ smoked only e-cigarettes, $39.74 \%(n=93)$ smoked only traditional cigarettes, $11.97 \%(\mathrm{n}=28)$ were dual users (use both e-cigarettes and traditional cigarettes), and $32.91 \%$ $(n=77)$ did not use tobacco products.

Responding to the question, "Where do you get your e-cigarettes?", 45.31\% ( $n=106)$ stated they obtained the product from friends/acquaintances, $23.93 \%(n=56)$ ordered online, $30.76 \%(n=72)$ purchased from tobacco shops, $22.65 \%$ $(n=53)$ obtained from "other" sources (various shopping centers).

When asked about the type of symptoms they may have experienced during or after using e-cigarettes, the most commonly mentioned symptoms were a feeling of dryness in the mouth/throat and cough (reported by $36.75 \%, n=86$ ), increased sputum (reported by $26.15 \%, n=61$ ), and excessive smoking desire (reported by $13.67 \%, n=32$ ). The majority, $70.08 \%(n=164)$ of the participants, reported using e-cigarettes in their homes' indoor spaces, $44.44 \%(n=104)$ in the indoor spaces of their workplaces, and $4.70 \%(n=11)$ in public vehicles, while $31.20 \%(n=73)$ of the users reported that they used e-cigarettes in the home while children were present.

The reasons given for using e-cigarettes differed according to smoking status. When participants' stated reasons for starting e-cigarettes were evaluated, the top three most frequently cited reasons were a desire to quit smoking completely at a rate of $74.79 \%(n=175)$, the absence of a foul smell at a rate of $73.93 \%(n=173)$, and being perceived as less harmful than smoking at a rate of $67.10 \%(n=157)$ (Table 2).

Of the 234 e-cigarette users, 170 reported that they also had quit using e-cigarettes. The top three most frequently cited reasons for quitting e-cigarettes were: Not helping to quit traditional cigarettes [26.47\% $(n=45)]$, the risks of using e-cigarettes [22.35\% ( $n=38)]$, and concerns about the safety of the product $[22.35 \%(n=38)]$ (Table 3$)$.

\section{Discussion}

We have found that the most common reason for e-cigarette usage was trying to quit smoking or to reduce the health risks of regular smoking and, $30.76 \%$ of e-cigarette users could buy e-cigarettes easily, although the sale is prohibited in our country.

The high proportion of e-cigarette users were male, and over $85.89 \%$ of the cases had a high school education. Of the cases, $83.76 \%$ had ordinary income jobs. The most common reason to commence using e-cigarettes was the desire to quit smoking completely, followed by a disturbing bad smell being perceived as less harmful than smoking. 


\begin{tabular}{|l|l|l|l|}
\hline \multicolumn{5}{|l}{ Table 2. The reasons for using/choosing e-cigarette } \\
\hline $\begin{array}{l}\text { E-cigarette use/reasons } \\
\text { to choose }\end{array}$ & $\begin{array}{l}\text { Disagree } \\
\mathbf{n}(\%)\end{array}$ & $\begin{array}{l}\text { Partially } \\
\text { agree } \\
\mathbf{n}(\%)\end{array}$ & $\begin{array}{l}\text { Totally } \\
\text { agree } \\
\mathbf{n}(\%)\end{array}$ \\
\hline $\begin{array}{l}\text { Starting e-cigarettes } \\
\text { out of curiosity }\end{array}$ & $103(44.02)$ & $53(22.65)$ & $78(33.33)$ \\
\hline $\begin{array}{l}\text { More pleasurabl than } \\
\text { smoking }\end{array}$ & $131(55.98)$ & $40(17.10)$ & $63(26.92)$ \\
\hline $\begin{array}{l}\text { Thinking it as less } \\
\text { harmful than smoking }\end{array}$ & $44(18.80)$ & $33(14.10)$ & $157(67.10)$ \\
\hline $\begin{array}{l}\text { The thought of not } \\
\text { exposing those around } \\
\text { me to smoke }\end{array}$ & $59(25.22)$ & $44(18.80)$ & $131(55.98)$ \\
\hline $\begin{array}{l}\text { Its being cheaper than } \\
\text { cigarettes }\end{array}$ & $114(48.71)$ & $50(21.37)$ & $70(29.92)$ \\
\hline $\begin{array}{l}\text { Thinking it will reduce } \\
\text { stress better than } \\
\text { smoking }\end{array}$ & $114(48.71)$ & $51(21.80)$ & $69(29.49)$ \\
\hline $\begin{array}{l}\text { Thinking it will help } \\
\text { reduce the number of } \\
\text { cigarettes smoked }\end{array}$ & $51(21.80)$ & $30(12.82)$ & $153(65.38)$ \\
\hline $\begin{array}{l}\text { Wanting to quit } \\
\text { smoking completely }\end{array}$ & $37(15.81)$ & $22(9.40)$ & $175(74.79)$ \\
\hline My friends' using it & $113(48.29)$ & $42(17.95)$ & $79(33.76)$ \\
\hline $\begin{array}{l}\text { Liking taste of } \\
\text { e-cigarette }\end{array}$ & $69(29.49)$ & $48(20.51)$ & $117(50.0)$ \\
\hline $\begin{array}{l}\text { Its having no bad smell } \\
\text { used indoors }\end{array}$ & $40(17.10)$ & $21(8.97)$ & $173(73.93)$ \\
\hline $\begin{array}{l}\text { Its being able to be } \\
\text { us }\end{array}$ & $72(30.77)$ & $32(13.68)$ & $130(55.55)$ \\
\hline
\end{tabular}

A wide variety of chemicals in e-cigarettes, including propylene glycol, glycerol, ethylene glycol, polyethylene glycol (PEG400), amino-tadalafil, rimonabant, cannabinoid, nitrosamines, formaldehyde, acetaldehyde ketone, mercury, tetramethylpyrazine, nicotine, artificial flavors, and various other carcinogenic chemicals, have been identified in e-cigarettes. Multinational tobacco companies claim that e-cigarettes are a "safer", "less harmful" alternative to regular cigarettes and an "adequate" method for smoking cessation $(4,6,8)$.

Nicotine concentration peaks within five minutes of inhaling an e-cigarette (18). Acute exposure to nicotine can cause headache, dizziness, nausea, and vomiting. Liquid nicotine in the cartridge of an e-cigarette can cause acute poisoning. The repeated use of the cartridge can raise the level of nicotine to toxic levels (19). This activity commonly causes oral and throat irritation, dry cough, dry eye, gastrointestinal symptoms, and local irritation. An increase in heart rate, short-term shortness of breath, headache, and sore throat are also reported. Nitrosamines contained in the product are known to be carcinogens. There are also studies showing that it may cause decreased respiratory function

\begin{tabular}{|l|l|l|l|}
\hline \multicolumn{4}{|l}{ Table 3. Reasons for stopping e-cigarettes } \\
$\begin{array}{l}\text { Reasons for stopping } \\
\text { e-cigarettes }\end{array}$ & $\begin{array}{l}\text { Disagree } \\
\mathbf{n}(\%)\end{array}$ & $\begin{array}{l}\text { Partially } \\
\text { agree } \\
\mathbf{n}(\%)\end{array}$ & $\begin{array}{l}\text { Totally } \\
\text { agree } \\
\mathbf{n}(\%)\end{array}$ \\
\hline $\begin{array}{l}\text { Its being costly, } \\
\text { expensive }\end{array}$ & $155(91.18)$ & $9(5.29)$ & $6(3.53)$ \\
\hline Disliking the taste & $152(89.42)$ & $9(5.29)$ & $9(5.29)$ \\
\hline $\begin{array}{l}\text { Its being too } \\
\text { complicated to use, } \\
\text { impractical }\end{array}$ & $137(80.59)$ & $18(10.59)$ & $15(8.82)$ \\
\hline $\begin{array}{l}\text { Being concerned about } \\
\text { the risks }\end{array}$ & $119(70.0)$ & $13(7.65)$ & $38(22.35)$ \\
\hline Not feeling like smoking & $116(68.24)$ & $20(11.76)$ & $34(20.0)$ \\
\hline $\begin{array}{l}\text { Its not reducing the } \\
\text { number of cigarettes } \\
\text { smoked }\end{array}$ & $120(70.59)$ & $13(7.65)$ & $37(21.76)$ \\
\hline $\begin{array}{l}\text { Its not helping to quit } \\
\text { smoking }\end{array}$ & $116(68.24)$ & $9(5.29)$ & $45(26.47)$ \\
\hline Being ashamed to use & $158(92.94)$ & $5(2.94)$ & $7(4.12)$ \\
\hline $\begin{array}{l}\text { Worrying about being } \\
\text { addicted to e-cigarettes }\end{array}$ & $138(81.18)$ & $14(8.24)$ & $18(10.59)$ \\
\hline $\begin{array}{l}\text { Its having too much } \\
\text { smoke }\end{array}$ & $146(85.89)$ & $9(5.29)$ & $15(8.82)$ \\
\hline $\begin{array}{l}\text { Being tired of carrying } \\
\text { the e-cigarette tool }\end{array}$ & $132(77.65)$ & $16(9.41)$ & $22(12.94)$ \\
\hline $\begin{array}{l}\text { Difficulties in liquid } \\
\text { supply }\end{array}$ & $129(75.88)$ & $8(4.71)$ & $33(19.41)$ \\
\hline $\begin{array}{l}\text { Having concerns about } \\
\text { its safety }\end{array}$ & $121(71.18)$ & $11(6.47)$ & $38(22.35)$ \\
\hline
\end{tabular}

$(18,19,20,21)$. In humans, e-cigarette use has been associated with multiple cases of acute lung injury and acute respiratory distress syndrome (ARDS) (22).

Although there are many questions about the efficacy of e-cigarettes as a smoking cessation tool or the longterm health effects of the product, multinational tobacco companies have managed to split those who oppose the use of e-cigarettes for tobacco control (23). Legal regulations regarding e-cigarettes differ among countries. Some countries entirely ban electronic cigarettes, while others have no regulations.

For instance, in the United Kingdom, it is not forbidden to sell, use, and advertise e-cigarettes. However, in Turkey, following an amendment made to the law in 2013, the advertisement of e-cigarettes, sales, and smoking in indoor places is prohibited.

Despite this ban, the use of e-cigarettes in Turkey and the world has increased in recent years. Worldwide, $3.7 \%$ of adults use e-cigarettes every day or several days a week. More than $20 \%$ of adults aged $18-20$ years have tried e-cigarettes (5).

The device's stylish designs, the perception that it is harmless or less harmful than traditional cigarettes, and 
the presentation of different flavors have contributed to the increase in the prevalence of e-cigarette use among young adults (24). When the sociodemographic characteristics of e-cigarette users are examined in systematic reviews, it is seen that it is prevalent in males, adolescents, young adults, and people with relatively higher education levels (25). This situation is compatible with the study data.

In a study conducted in European Union countries, $70.9 \%$ of non-smokers, $63.1 \%$ of ex-smokers, and $45.7 \%$ of smokers reported that they supported the ban on e-smoking in public places (26). Despite the ban on tobacco and products in closed areas in Turkey, in our study, $70.08 \%$ of e-cigarette users continued to use e-cigarettes at home, $44.44 \%$ at work, and $4.70 \%$ in public vehicles. This situation suggests that tobacco controls have been insufficient.

In this study, the first reason for using e-cigarettes was the desire to quit smoking. In another study, the reason for starting e-cigarettes was stated as being curious (27).

Although the participants stated that the most compelling reason for starting smoking was to give up traditional smoking, it is known that they continue to smoke. Switching to another tobacco product to quit smoking may result in low motivation for making other attempts to quit. This information was an important warning for us to review the services we provide to the public to quit smoking.

In a study conducted with 3,878 e-cigarette users, among the most common reasons for starting e-cigarettes, curiosity was reported to be the first with the rate of $53 \%$, the suggestion of friends or family members to be the second with the rate of $34 \%$, while $30 \%$ had the idea to quit smoking (27). It was observed that the thoughts of quitting smoking, not having a foul odor, and being less harmful than smoking were dominant when starting e-cigarettes. In the literature about e-cigarettes, it is seen that people often initiate e-cigarette use to quit or reduce traditional smoking, which is consistent with our study $(28,29)$.

Doran et al. (30) studied whether e-cigarette use reduced smoking or not. They found that e-cigarette usage sustained smoking habits and even increased smoking. The fact that using e-cigarettes may sustain or even increase a person's smoking rather than decrease may explain the same behavioral effect of e-cigarette use and smoking. E-cigarette users continue their behavioral dependence, and to reach the same nicotine level, they overuse e-cigarettes, which have less nicotine than traditional cigarettes, or use both e-cigarettes and traditional cigarettes (dual use) (31). Our study consisted of $11.97 \%(n=28)$ of dual users.

\section{Study Limitations}

This is a survey study; the proportions of smoking, e-cigarette use, quitting smoking, and restarting are based on the participants' statements. Since the people reached through the social platform were surveyed, the data may not include all e-cigarette users. The questions were constructed according to current data by researchers because there was not an available validated questionnaire about e-cigarette usage. So, this survey cannot represent the complete characteristics of e-cigarette users.

\section{Conclusion}

In this study, it was seen that the most important reason for starting to use e-cigarettes was the desire to quit smoking. For this reason, we think it is essential to inform the public about that e-cigarettes are not a smoking cessation method.

The tobacco industry mainly targets young people and users who want to quit smoking with e-cigarette ads. It should be explained to the public that e-cigarettes are harmful and are yet another kind of tobacco product. We should fight against the increased usage of e-cigarettes to avoid losing the gains obtained in tobacco control.

\section{Ethics}

Ethics Committee Approval: Approval for the study was obtained from the Adana Numune Training and Research Hospital Local Ethics Committee (protocol no: 26.04.201757).

Informed Consent: Verbal consent was obtained from the patients for the questionnaire.

Peer-review: Internally peer-reviewed.

\section{Authorship Contributions}

Surgical and Medical Practices: A.T., P.D.Ç., M.A.U., Concept: A.T., P.D.Ç., M.A.U., Design: A.T., P.D.Ç., M.A.U., Data Collection or Processing: A.T., P.D.Ç., M.A.U., Analysis or Interpretation: A.T., P.D.Ç., M.A.U., Literature Search: A.T., P.D.Ç., M.A.U. Writing: A.T., P.D.Ç., M.A.U.

Conflict of Interest: No conflict of interest was declared by the authors.

Financial Disclosure: The authors declared that this study received no financial support.

\section{References}

1. Lichtenberg K. E-cigarettes: current evidence and policy. Mo Med. 2017;114:335-338. [Crossref]

2. Wang W, He Z, Feng N, Cai Y. Electronic cigarette use in China: Awareness, prevalence and regulation Tob Induc Dis. 2019;17:30. [Crossref]

3. Etter JF, Bullen C, Flouris AD, Laugesen M, Eissenberg T. Electronic nicotine delivery systems: a research agenda. Tob Control. 2011;20:243-248. [Crossref]

4. Givens A, Cheng P-S. I-Team: E-cigarettes, used to smoke marijuana, spark new concerns. 4 New York. October 11, 2013. Last Accessed Date: 19.05.2014. Available from: http://www. nbcnewyork.com/investigations/ 
ECigarettes-Drugs-Marijuana-VaporPens-Smoking-I-Team-227269001. html. [Crossref]

5. Schoenborn CA, Gindi RM. electronic cigarette use among adults: United States, 2014. NCHS Data Brief. 2015:1-8. [Crossref]

6. Glasser AM, Collins L, Pearson JL, Abudayyeh H, Niaura RS, Abrams DB, et al. Overview of electronic nicotine delivery systems: a systematic review. Am J Prev Med. 2017;52:e33-e66. doi: 10.1016/j.amepre.2016.10.036. [Crossref]

7. Daglı E, Sönmez Peçe Ü, Güner M. Electronic Cigarette: Situation Analysis in Turkey and in the World. STED. 2017;26(Suppl):12-17. [Crossref]

8. Grana R, Benowitz N, Glantz SA. E-cigarettes: a scientific review. Circulation. 2014;129:1972-1986. [Crossref]

9. Cheng T. Chemical evaluation of electronic cigarettes. Tob Control. 2014;23(Suppl 2):ii11-ii17. doi: 10.1136/tobaccocontrol-2013-051482. [Crossref]

10. Kim HJ, Shin HS. Determination of tobacco-specific nitrosamines in replacement liquids of electronic cigarettes by liquid chromatographytandem mass spectrometry.J Chromatogr A. 2013;1291:48-55.

11. Dai H, Leventhal AM. Prevalence of e-cigarette use among adults in the United States, 2014-2018. JAMA. 2019;322:1824-1827. [Crossref]

12. E- cigarette use in Canada. Last Accessed Date: 28.09.2020. Available from: https://uwaterloo.ca/tobacco-use-canada/e-cigarette-use-canada. [Crossref]

13. Türkiye Kanser Kontrol Programı. Available date: 28.09.2020. Available from: https://hsgm.saglik.gov.tr/depo/birimler/kanserdb/yayinlar/Kitaplar /TURKIYE_KANSER_KONTROL_PROGRAMI_2016.pdf. [Crossref]

14. Resmi Gazate Kararı, Kanun no: 6487. Available date: 28.09 .2020 . Available from: https://www.resmigazete.gov.tr/eskiler/2013/06/20130611-1.htm. [Crossref]

15. Göktaş S, Önsüz MF, Işıklı B, Metintaş S. E-Sigara. ESTÜDAM Halk Sağlığı Dergisi. 2018;3:55-62. [Crossref]

16. Güner M, Peçe Ü, Dağlı E, Ay P, Yıldız F, Elbek O. Elektronik sigara konulu Türkçe internet sitelerinde içerik araştırması- PS-79 Türk Toraks Kongresi 2016. [Crossref]

17. Uysal MA, Niksarlıoğlu EY, Çarkoğlu A, Uysal Ö, KutlukAC, Karadağ B. Digital Epidemiology: can google trends give some information about electronic cigarette use in Turkey? Turk Thorac J. 2018;19(Suppl 1):S179-S180. [Crossref]

18. Dinakar Ch, O'Connor GT. The health effects of electronic cigarettes. N Engl J Med. 2016;375:2608-2609. [Crossref]
19. Callahan-Lyon P. Electronic cigarettes: human health effects. Tob Control. 2014;23(Suppl 2):ii36-ii40. doi: 10.1136/tobaccocontrol-2013-051470 [Crossref]

20. Flouris AD, Chorti MS, Poulianiti KP, Jamurtas AZ, Kostikas K, Tzatzarakis $\mathrm{MN}$, et al. Acute impact of active and passive electronic cigarette smoking on serum cotinine and lung function. Inhal Toxicol. 2013;25:91-101. [Crossref]

21. Chorti M, Poulianti K, Jamurtas A, Kostikas K, Tzatzarakis MN, Vynias D, et al. Effects of active and passive electronic and tobacco cigarette smoking on lung function. Toxicol Lett. 2012;21:64. [Crossref]

22. Moshensky A, Hepokoski M, Bojanowski CM, Nguyen N, Crotty Alexander LE. Chronic inhalation of electronic (E)-cigarette vapor increases susceptibility to acute lung injury. Am J Respir Crit Care Med. 2018;197:A3568. [Crossref]

23. Novotny TE, van Schalkwyk MCl. How Should Physicians in Low- and Middle-Income Countries Regard Electronic Nicotine Delivery Systems to Facilitate Smoking Cessation? AMAJ Ethics. 2020;22:E82-E92. https://doi. org/10.1001/amajethics.2020.82 [Crossref]

24. Staudt MR, Salit J, Kaner RJ, Hollmann C, Crystal RG. Altered lung biology of healthy never smokers following acute inhalation of E-cigarettes. Respir Res. 2018;19:78. [Crossref]

25. Hartwell G, Thomas S, Egan M, Gilmore A, Petticrew M. E-cigarettes and equity: a systematic review of differences in awareness and use between sociodemographic groups. Tob Control. 2017;26:e85-e91. doi:10.1136/ tobaccocontrol-2016-053222 [Crossref]

26. Laverty AA, Filippidis FT, Fernandez E, Vardavas Cl. E-cigarette use and support for banning e-cigarette use in public places in the European Union. Prev Med. 2017;105:10-14. [Crossref]

27. Pepper JK, Ribisl KM, Emery SL, Brewer NT. Reasons for starting and stopping electronic cigarette use. Int J Environ Res Public Health. 2014;11:10345-10361. [Crossref]

28. Boyle RG, Richter S, Helgertz S. Who is using and why: prevalence and perceptions of using and not using electronic cigarettes in a statewide survey of adults. Addict Behav Rep. 2019;10:100227.2019. [Crossref]

29. Burstyn I. Peering through the mist: systematic review of what the chemistry of contaminants in electronic cigarettes tells us about health risks. BMC Public Health. 2014;14:18. [Crossref]

30. Doran N, Brikmanis K, Petersen A, Delucchi K, Al-Delaimy,WK, Luczak S, et al. Does e-cigarette use predict cigarette escalation? A longitudinal study of young adult non-daily smokers. Prev Med. 2017;100:279-284. [Crossref]

31. Wills TA, Sargent JD. Do E-cigarettes reduce smoking? Prev Med. 2017;100:285-286. [Crossref] 